\title{
PEMBERDAYAAN WARGA KETERBELAKANGAN MENTAL DI DESA KARANGPATIHAN PONOROGO MELALUI FRUTABLE GREDEN
}

\author{
Retno Wulandari $^{1}$, Hana Anjasari ${ }^{1}$, Novita Dwi Wulandari ${ }^{1}$, Mitha Nur Jayanti², \\ Gunarhadi $^{3}$ \\ ${ }^{1}$ Pendidikan Luar Biasa, Fakultas Keguruan dan Ilmu Pendidikan, Universitas Sebelas Maret, \\ Jl. Ir Sutami No 36 A, Kentingan, Jebres, Surakarta, 57126 \\ ${ }^{2}$ Penyuluhan dan Komunikasi Pertanian, Fakultas Pertanian,Universitas Sebelas Maret \\ Jl. Ir Sutami No 36 A, Kentingan, Jebres, Surakarta, 57126 \\ ${ }^{3}$ Pascasarjana, Universitas Sebelas Maret \\ Jl. Ir. Sutami No. 36A, Kentingan, Jebres, Surakarta, 57126 \\ Email Penulis Korespondensi: Rewulanndari@gmail.com
}

\begin{abstract}
Abstrak
Desa Karangpatihan merupakan salah satu desa yang berada di pelosok selatan-barat Kabupaten Ponorogo, Kecamatan Balong, dimana terdapat sebagian masyarakatnya merupakan penyandang keterbelakangan mental dengan kondisi geografis tanah yang kurang subur dan cenderung tandus karena berdiri di bawah kaki pegunungan berkapur. Faktor geografis, kemiskinan dan tingkat pendidikan yang rendah mengakibatkan warga mengalami pemasalahan pola hidup, khususnya berkaitan dengan konsumsi makanan yang bergizi. Pengadaan program frutable greden bertujuan untuk meningkatkan konsumsi sayur dan buah, sekaligus memberdayakan masyarakat menjadi lebih produktif. Kegiatan dalam program frutable greden meliputi pembangunan frutable greden atau semacam green house, penananaman, serta perawatan tanaman yang dilakukan oleh warga keterbelakangan mental. Hasil panen dari perawatan tanaman dapat dikonsumsi sebagai bentuk pemenuhan gizi warga. Proses pemberdayaan dilangsungkan secara bertahap mulai dari tahap sosialisasi, pembangunan frutable greden, penanaman bibit tanaman, perawatan tanaman hingga pemanenan. Bentuk pemberdayaannya berupa melibatkan partisipasi warga keterbelakangan mental secara aktif dengan bantuan dari kader frutable greden. Kader disini merupakan salah satu anggota keluarga warga keterbelakangan mental yang normal yang dipilih dan bertugas untuk membantu tim dalam menggerakkan pelaksanaan proses pemberdayaan. Hasil pemanenan dari tanaman di green house ini dapat dikonsumsi dijadikan bahan pangan tambahan masyarakat sebagai bentuk pemenuhan gizi.
\end{abstract}

Kata kunci : Green house, Keterbelakangan Mental, Pemberdayaan Masyarakat

\begin{abstract}
Karangpatihan Village is one of the villages in the south-west corner of Ponorogo Regency, Balong Subdistrict, where there are some people who are mentally retarded with geographic conditions that are less fertile and tend to be barren because they stand under the feet of the calcareous mountains. Geographical factors, poverty, and low levels of education result in people having lifestyle problems, especially related to the consumption of nutritious foods. The procurement of frutable greden programs aims to increase the consumption of vegetables and fruits, while empowering people to be more productive. Activities in the frutable greden program include the development of frutable greden or some kind of green house, planting, and treatment of plants by mental retardation people. The harvest can be consumed as a form of nutrition fulfillment. The empowerment process is carried out in stages starting from the stages of socialization, frutable greden construction, growing of plant seeds, maintenance of plants to harvesting. The form of empowerment involves active participation of people with mental retardation with the help of frutable greden cadre. Cadres here are one of the family
\end{abstract}


members of mental retardation people who are selected and haved a task to assist the team as a pioneer the implementation of the empowerment process. Yield from plants in this green house can be consumed as additional food for the community as nutrition fulfillment.

\section{Keywords: Community Empowerment, Green house, Mental Retardation}

\section{PENDAHULUAN}

Semakin tumbuh dan berkembangnya manusia dalam kehidupan, menyebabkan tubuh perlu asupan gizi yang baik. Pemenuhan gizi merupakan hal yang penting dalam kehidupan. Pemenuhan gizi dimulai sejak manusia berada dalam kandungan hingga seumur hidup. Gizi yang seimbang akan membuat hidup menjadi sehat dan berkualitas. Semua orang berhak untuk memenuhi kebutuhan gizinya.

Konsumsi asupan makanan yang baik dapat memenuhi takaran gizi seimbang, yakni porsi makan yang dikonsumsi dalam satu piring terdiri dari $50 \%$ buah dan sayur, dan $50 \%$ sisanya terdiri dari karbohidrat dan protein. Tubuh manusia memerlukan beragam vitamin dan mineral agar dapat bekerja dengan baik. Keduanya memiliki peranan penting bagi proses pertumbuhan dan metabolisme dalam tubuh. Untuk memenuhi kebutuhan tersebut, manusia setiap harinya harus mengonsumsi makanan yang mengandung vitamin dan mineral, dikarenakan tubuh manusia tidak mampu memproduksi vitamin ataupun mineral itu sendiri. Beragam jenis sayuran dan buah-buahan dapat dikonsumsi untuk memenuhi kebutuhan vitamin dan mineral yang diperlukan tubuh. Menyinggung mengenai hal konsumsi sayur dan buah masyarakat Indonesia sampai sekarang masih memiliki kesadaran yang rendah mengenai pentingnya mengonsumsi sayur dan buah secara rutin. Padahal mengonsumsi sayur dan buah dalam jumlah yang cukup akan bermanfaat baik bagi kesehatan tubuh dan otak.

Berdasar Data Riset Kesehatan Dasar (Riskesdas) 2013 menunjukkan bahwa 93,5\% masyarakat Indonesia tidak mengonsumsi sayur dan buah dengan cukup. Kurangnya konsumsi sayur dan buah dapat meningkatkan risiko terjadinya penyakit tidak menular (PTM), di antaranya meliputi penyakit stroke, penyakit jantung, obesitas, diabetes, hipertensi dan kanker. WHO bahkan menyebutkan bahwa kekurangan sayur dan buah dapat menyebabkan kematian akibat saluran cerna sebesar 14\%, kematian akibat penyakit jantung koroner sebesar $11 \%$, dan kematian akibat stroke sebesar $9 \%$.

Nuri Andarwulan dalam liputan6.com menyatakan bahwa berdasarkan survei konsumsi buah dan sayuran masyarakat Indonesia baru mencapai 180 gram per kapita per hari, padahal standar WHO 400 gram per kapita per hari. Rendahnya konsumsi buah dan sayur masyarakat Indonesia disebabkan oleh berbagai faktor, di antaranya: rendahnya kesadaran atau terbatasnya pengetahuan untuk mengonsumsi sayuran dan buah-buahan. Selain itu faktor kemiskinan juga dapat menjadi salah satu penyebab rendahnya konsumsi sayuran dan buah-buahan. Faktor lainnya dapat disebabkan pula oleh kondisi geografis wilayah tertentu, yang tidak mendukung tumbuhnya tanaman sayuran dan buah-buahan, meskipun ada tentunya tanaman tersebut akan sulit tumbuh dan menghasilkan buah.

Almatsier (2010) menyebutkan bahwa sayur dan buah mengandung vitamin, mineral, dan nutrisi lainnya yang dibutuhkan tubuh. Kurangnya konsumsi sayur dan buah bisa menjadi penyebab malnutrisi. Menurut Pieter, H.Z., Janiwarti, B. dan Saragih, NS.M. (2011) dalam buku Pengantar Psikopatologi bahwa aspek gizi seperti kwashiorkor, marasmus, dan malnutrisi juga dapat menjadi penyebab kelainan mental atau mental retardation.

Seperti halnya yang dialami sebagian warga desa karangpatihan, kecamatan Balong, Kabupaten Ponorogo yang mengalami keterbelakangan mental. Dari kondisi tanah yang merupakan lahan berkapur dan tandus sangat tidak memungkinkan untuk ditanami sayur dan buah ditambah dengan letak geografis yang berada di pelosok dan akses keluar desa yang belum memadai, sehingga konsumsi sayur dan buah warga Karangpatihan pun rendah. Kurangnya asupan yang dibutuhkan tubuh yang berasal dari buah dan sayur ini menjadi salah satu dari beberapa faktor penyebab mental retardation yang dialami warga. Dikarenakan sebagian warga mengalami keterbelakangan mental, maka desa ini lebih dikenal dengan sebutan kampung idiot. 
Kampung Idiot Desa Karangpatihan ini merupakan sebuah kampung pemukiman warga yang sebagian warganya, baik anak-anak dan orang dewasa mengalami hambatan disabilitas, seperti bisu, keterbelakangan mental dan lamban pikir. Di Desa Karangpatihan sendiri saat ini terdapat 98 warga penyandang keterbelakang mental, yang tersebar merata di keempat dusun, dengan rincian sebagai berikut:

Tabel 1. Jumlah Penduduk Normal (KK) dan Tunagrahita per Dusun 2017

\begin{tabular}{lll}
\hline $\begin{array}{l}\text { Nama } \\
\text { Dukuh }\end{array}$ & Normal & $\begin{array}{l}\text { Keterbela- } \\
\text { kangan } \\
\text { Mental }\end{array}$ \\
\hline $\begin{array}{l}\text { Dukuh } \\
\text { Krajan }\end{array}$ & 435 & 13 \\
\hline $\begin{array}{l}\text { Dukuh } \\
\text { Bibis }\end{array}$ & 234 & 7 \\
\hline $\begin{array}{l}\text { Dukuh } \\
\text { Bendo }\end{array}$ & 304 & 10 \\
\hline $\begin{array}{l}\text { Dukuh } \\
\text { Tanggung- } \\
\text { rejo }\end{array}$ & 897 & 68 \\
\hline
\end{tabular}

Kampung ini terletak di kawasan gunung kapur dan memiliki tanah yang tandus. Kondisi geografis, faktor kemiskinan, serta minimnya tingkat pendidikan warga Kampung Idiot Desa Karangpatihan menyebabkan permasalahan pola hidup, khususnya berkaitan dengan konsumsi makanan yang bergizi. Masyarakat setempat hanya dapat mengandalkan beberapa jenis makanan yang berasal dari kebun/ladang sekitar yang juga tandus/kering. Sedikit jenis tanaman sayur dan buah yang dapat tumbuh di tanah yang tandus. Jumlah sayur dan buah yang diambil serta dikonsumsi warga masih belum mampu memenuhi tingkat standar asupan sayur dan buah yang harus dikonsumsi tiap harinya.

Rendahnya tingkat konsumsi sayuran dan buah-buahan pada warga Kampung Idiot ini dapat diatasi melalui upaya pemenuhan standar asupan sayuran dan buah-buahan, yakni melalui pengadaan "Frutable Greden" (Fruits and Vegetables of Green Garden). Sasaran dari program "Frutable Greden" ini yaitu warga Kampung Idiot.

Pemberdayaan masyarakat perlu dilakukan untuk pemenuhan kebutuhan gizi dan nutrisi, serta membuat warga Desa Karangpatihan yang menyandang keterbelakangan mental menjadi produktif. Pemberdayaan masyarakat yang dilakukan berupa menanam sayur di green house yang sudah disiapkan di tiga titik tempat.

Kegiatan ini kami harapkan mampu berkelanjutan agar warga Desa Karangpatihan produktif untuk menghasilkan sayur dan buah, serta gizi dan nutrisi warga dapat tercukupi.

\section{METODE PELAKSANAAN}

Kegiatan pengabdian berlokasikan di Dusun Tanggungrejo, Karangpatihan dan dilaksanakan selama 2 bulan yaitu pada bulan April hingga Mei. Pelaksanaan program dibagi menjadi tiga kelompok atau tiga titik. Dengan masing-masing kelompok terdiri sebanyak lima kepala keluarga (KK). Tiap-tiap kepala keluarga memiliki anggota keluarga dengan keterbelakangan mental. Metode pelaksanaan program dilakukan melalui beberapa tahapan (Tabel 2).

Tabel 2. Tahapan pelaksanaan program Frutable Greden

\begin{tabular}{|c|c|c|}
\hline No & Kegiatan & $\begin{array}{l}\text { Waktu } \\
\text { (Bulan, } \\
\text { Minggu ke) }\end{array}$ \\
\hline 1 & $\begin{array}{l}\text { Konsultasi penentuan } \\
\text { lahan; survei harga alat } \\
\text { dan bahan; serta } \\
\text { penandatanganan MoU }\end{array}$ & $\begin{array}{l}\text { April, } \\
\text { Minggu ke-I }\end{array}$ \\
\hline 2 & $\begin{array}{l}\text { Sosialisasi program } \\
\text { "Frutable Greden" } \\
\text { pada warga sasaran }\end{array}$ & $\begin{array}{l}\text { April, } \\
\text { Minggu ke- } \\
\text { II }\end{array}$ \\
\hline 3 & $\begin{array}{l}\text { Pembelian alat dan } \\
\text { bahan }\end{array}$ & $\begin{array}{l}\text { April, } \\
\text { Minggu ke- } \\
\text { III }\end{array}$ \\
\hline 4 & $\begin{array}{l}\text { Pembangunan green } \\
\text { house di tiga titik }\end{array}$ & $\begin{array}{l}\text { April, } \\
\text { Minggu ke- } \\
\text { II hingga } \\
\text { Mei, } \\
\text { Minggu ke- } \\
\text { II }\end{array}$ \\
\hline 5 & $\begin{array}{l}\text { Penanaman } \\
\text { sayur dan buah }\end{array}$ & $\begin{array}{l}\text { Mei, } \\
\text { Minggu ke-I } \\
\text { hingga } \\
\text { Minggu ke- } \\
\text { II }\end{array}$ \\
\hline 6 & $\begin{array}{l}\text { Pendampingan dan } \\
\text { peninjauan pelaksanaan } \\
\text { program }\end{array}$ & $\begin{array}{l}\text { Mei, } \\
\text { Minggu ke-I } \\
\text { hingga } \\
\text { Minggu ke- } \\
\text { IV }\end{array}$ \\
\hline 7 & Pemanenan hasil tanam & $\begin{array}{l}\text { Mei, } \\
\text { Minggu ke- } \\
\text { IV }\end{array}$ \\
\hline
\end{tabular}


Selain bertujuan untuk mengenalkan program "Frutable Greden", sosialisasi juga bertujuan untuk menanamkan pada warga akan pentingnya mengkonsumsi sayur dan buah secara rutin, serta pemilihan kader "Frutable Greden" yang bertugas untuk membantu tim dalam melaksanakan program (sebagai pemantau dan penggiat pelaksanaan program).

Adapun alat dan bahan yang digunakan untuk pembangunan green house dan penanaman sayur dan buah, meliputi: bambu, paku, paranet, palstik UV, tali, palu, benih/bibit, pupuk, polybag, dan lain-lain. Pembangunan green house dan penanaman sayur dan buah dilakukan secara bersama sesuai dengan kelompok yang ditentukan.

Guna mendukung keberhasilan program, dilakukan pendampingan dan peninjauan pelaksanaan program oleh Tim PKM yang dibantu oleh kader dan mitra, sehingga nantinya program dapat berjalan secara berkelanjutan.

\section{HASIL DAN PEMBAHASAN}

\section{Sosialisasi Program "Frutable Greden"}

Sosialisasi program dilaksanakan setelah mendapatkan pesetujuan dari pihak mitra dan dilakukan pada bulan April, minggu kedua, tepatnya pada tanggal 13 April 2019 di Rumah Harapan, pusat pemberdayaan warga keterbelakangan mental. Peserta sosialisasi adalah warga keterbelakangan mental dan warga normal yang berperan sebagai pendamping. Hal yang dilakukan dalam kegiatan sosialisasi ini meliputi pemberian penyuluhan terhadap warga sasaran mengenai pentingnya mengkonsumsi sayur dan buah secara rutin; pengenalan program, pemilihan kader; dan pembagian kelompok berdasar titik lokasi. Pada tahap soisalisasi ini tim melakukan survei dengan wawancara langsung dengan warga. Wawancara dilakukan didasarkan pada angket tentang frekuensi dan variasi sayur dan buah yang dikonsumsi warga.

Berdasarakan wawancara yang telah dilakukan diketahui bahwa tingkat konsumsi sayur dan buah warga masih rendah serta kurang beranekaragaman. Warga hanya mengonsumsi satu sampai dua kali sehari dengan dua jenis sayur yaitu daun singkong dan kenikir yang tumbuh secara liar ladang.

Tingkat keberhasilan sosialisasi dapat dilihat dari pemahaman warga yang dibuktikan dengan pemberian pertanyaan terkait materi yang disampaikan secara langsung.

\section{Pembangunan Green House dan Penanaman dan Perawatan Tanaman Sayur dan Buah.}

Pembangunan green house dilakukan melalui dua tahapan., meliputi: (1) Tahap persiapan antara lain: menentukan lokasi untuk pembangunan, menentukan desain green house, serta menyiapkan alat bahan. Terdapat tiga titik lokasi yang digunakan sebagai tempat untuk pembangunan green house. Penentuan lokasi dilakukan dengan survei dan telah melalui persetujuan dari pemilik lahan. Ketiga lahan tersebut merupakan pekarangan depan rumah warga. Luas green house yang dibangun disesuaikan dengan luas pekarangan rumah warga. Titik lokasi atau pos pertama dan ketiga berukuran $5 \times 4 \mathrm{~m}$, sedangkan pos kedua berukuran $3 \times 4 \mathrm{~m}$. (2) Tahap pembangunan, yaitu membangun green house pada lokasi. Dalam pembangunan green house ini bambu digunakan sebagai komponen bahan utama pembangunan. Adapun alat dan bahan lain yang digunakan, antara lain: paranet, tali, plastik UV, paku, kawat, gergaji, palu dan lain-lain. Pembangunan dilakukan secara bergotong royong menurut kelompok. Warga disabilitas bersama dengan warga normal secara aktif turut serta dalam kegiatan.

Setelah pembangunan green house_selesai, selanjutnya dilakukan kegiatan penanaman benih/bibit sayur dan buah, yang terdiri dari: kangkung, sawi, terong, cabai dan tomat. Penanaman dilakukan melalui dua tahap, meliputi: (1) Tahap persiapan yaitu menyiapkan alat dan bahan penanaman serta materi penyuluhan mengenai penanaman dan perawatan tanaman. Adapun alat dan bahan yang digunakan, antara lain: polybag, tanah, pupuk, sekop dan lainnya; (2) Tahap penanaman dan perawatan yaitu melalui kegiatan demonstrasi, warga dilatih mengenai bagaimana cara menanam benih/bibit dengan benar, juga cara merawatnya. Warga diberikan penyuluhan mengenai penanaman dan perawatan benih hingga tumbuh menjadi tanaman, serta pemanenan hasil tanam. Secara bergotong royong warga melakukan penanaman sesuai kelompok. Warga terdiri dari warga normal dan warga disabilitas. Kegiatan penanaman dan perawatan tanaman melibatkan peran kader, sehingga keberlangsungan pelaksanaan program dapat terkontrol dengan baik. 
Tingkat keberhasilan pelaksanaan pembangunan green house dapat dibuktikan dengan keaktifan anggota kelompok dalam kegiatan dan berdirinya green house sebanyak tiga buah di tiga titik lokasi atau pos yang berbeda.

Tingkat keberhasilan kegiatan penanaman dan perawatan tanaman sayur dan buah dapat diketahui melalui keaktifan anggota kelompok dan kader dalam proses penanaman; serta tumbuhnya tanaman sayur dan buah. Warga paham mengenai cara merawat tanaman dengan benar.

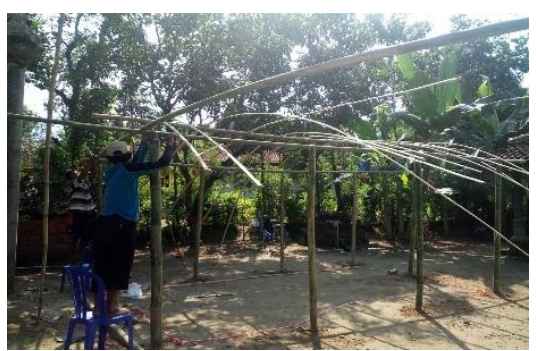

Gambar 1. Pembangunan green house oleh warga di salah satu titik lokasi

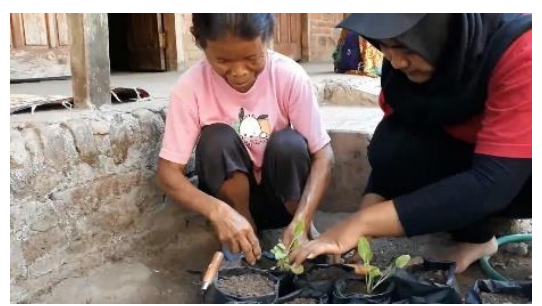

Gambar 2. Pemindahan bibit tanaman ke media tanam

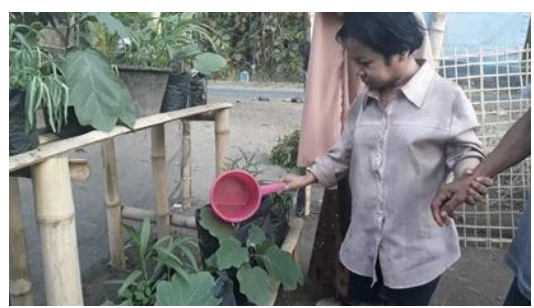

Gambar 3. Perawatan tanaman: penyiraman

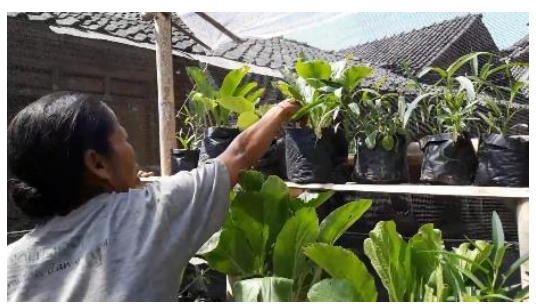

Gambar 4. Perawatan tanaman: pembersihan dari gulma

\section{Pemanenan Tanaman}

Ketika tanaman yang dirawat telah memasuki usia siap panen, warga secara bersama memanen tanaman dan hasilnya dibagi rata sesuai anggota kelompok masing-masing. Waktu pemanenan dimulai pada bulan Mei minggu keempat.

Setelah pemanenan pada masing-masing titik, tim melakukan evaluasi program dengan wawancara kembali pada warga terkait frekuensi dan variasi sayur dan buah yang dikonsumsi. Dari hasil wawancara menunjukkan bahwa terdapat peningkatan konsumsi sayur dan buah. Hal itu ditunjukkan dengan jenis dan frekuensi sayur yang dikonsumsi. Warga mengonsumsi sayur sebanyak tiga kali sehari dengan jenis yang lebih bervariasi dari sebelumnya yaitu kangkung, sawi dan terong.

Berdasarkan pemaparan data di atas dapat disimpulkan bahwa melalui program "Frutable Greden" warga terlibat secara aktif dalam menjalankan program dan mampu menghasilkan suatu yang bemanfaat yakni hasil panen tanaman sayur dan buah yang dapat dikonsumsi. Sehingga progam ini dapat dikatakan mampu meningkatkan tingkat konsumsi sayuran dan buah, selain itu warga menjadi lebih produktif.

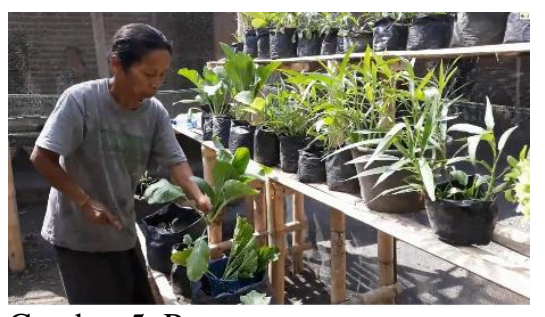

Gambar 5. Pemanenan tanaman sayur

\section{SIMPULAN DAN SARAN}

Secara umum pelaksanaan program "Frutable Greden" ini terlaksana dengan baik. Warga Kampung Idiot dapat memiliki wawasan tambahan mengenai penanaman, perawatan, hingga pemanenan tanaman sayur dan buah. Program "Frutable Greden" mampu mewadahi warga Kampung Idiot untuk meningkatkan tingkat konsumsi sayur dan buah serta mampu meningkatkan produktivitas sayur dan buah.

Dikarenakan kebermanfaatan program "Frutable Greden", kegiatan pelaksanaannya, maka perlu adanya keberlanjutan program dengan melibatkan peran kader sebagai pemantau keberjalanan program. Keberlanjutan program membutuhkan dukungan penuh dari 
pemerintah dan dinas terkait agar dapat terlaksana dengan baik.

\section{UCAPAN TERIMA KASIH}

Ucapan terima kasih terhadap pihak Belmawa Ristekdikti dan Bidang Kemahasiswaan dan Alumni Universitas Sebelas Maret yang telah memfasilitasi terselenggaranya kegiatan pengabdian ini berjalan dengan baik.

\section{DAFTAR PUSTAKA}

Almatsier S. (2010). Prinsip Dasar Ilmu Gizi. Jakarta: Gramedia Pustaka Utama

Deny, Septian. (2018). Konsumsi Sayuran dan Buah Masyarakat Masih di Bawah Standar FAO. https://www.liputan6.com/bisnis/read/ 3483541/konsumsi-sayuran-dan-buah masyarakat-ri masih-di-bawah-standar-fao. 2 September 2018
Pieter, H.Z., Janiwarti, B. dan Saragih, NS.M. (2011). Pengantar Psikopatologi untuk Keperawatan. Jakarta: Kencana.

Ramadhani, Yulaika. (2017). Yang Penting Gizi Seimbang, Bukan "4 Sehat 5 Sempurna". https://tirto.id/yang-penting-gizi-seimbangbukan-4-sehat-5-sempurna-czrP. 4 September 2018

Renaldi, Elwin, dan Zhou, Christina. (2018). Transformasi di Ponorogo Dari 'Kampung Idiot' Menjadi 'Desa Wisata'. https://www.abc.net.au/indonesian/2018-0625/kampung-idiot-jadi-desawisata/9846420. 30 Agustus 2018

Sekarsari, Bebby. (2017). Ini Akibat Kurangnya Konsumsi Sayur dan Buah. http://www.1health.id/id/article/ategory/seh at-a-z/ini-akibat kurangnya-konsumsisayur-dan buah.html. 3 September 2018 